\title{
Climatic Trends in Different Bioclimatic Zones in the Chitwan Annapurna Landscape, Nepal
}

\author{
Dol Raj Luitel ${ }^{1,2, *}$, Pramod K. Jha ${ }^{1}$, Mohan Siwakoti ${ }^{1}$, Madan Lall Shrestha ${ }^{3}$ and \\ Rangaswamy Munniappan 4 (D) \\ 1 Central Department of Botany, Tribhuvan University, Kritipur, Kathmandu 44600, Nepal; \\ pk.jha@cdbtu.edu.np (P.K.J.); m.siwakoti@cdbtu.edu.np (M.S.) \\ 2 Department of Plant Resources, Ministry of Forests and Environment, Kathmandu 44600, Nepal \\ 3 Nepal Academy of Science and Technology, Lalitpur 44600, Nepal; madan@smallearth.org.np \\ 4 IPM-IL Virginia Tech, Blacksburg, VA 23922, USA; rmuni@vt.edu \\ * Correspondence: Dolraj.735702@cdb.tu.edu.np
}

Received: 8 October 2020; Accepted: 17 November 2020; Published: 20 November 2020

\begin{abstract}
The Chitwan Annapurna Landscape (CHAL) is the central part of the Himalayas and covers all bioclimatic zones with major endemism of flora, unique agro-biodiversity, environmental, cultural and socio-economic importance. Not much is known about temperature and precipitation trends along the different bioclimatic zones nor how changes in these parameters might impact the whole natural process, including biodiversity and ecosystems, in the CHAL. Analysis of daily temperature and precipitation time series data (1970-2019) was carried out in seven bioclimatic zones extending from lowland Terai to the higher Himalayas. The non-parametric Mann-Kendall test was applied to determine the trends, which were quantified by Sen's slope. Annual and decade interval average temperature, precipitation trends, and lapse rate were analyzed in each bioclimatic zone. In the seven bioclimatic zones, precipitation showed a mixed pattern of decreasing and increasing trends (four bioclimatic zones showed a decreasing and three bioclimatic zones an increasing trend). Precipitation did not show any particular trend at decade intervals but the pattern of rainfall decreases after 2000AD. The average annual temperature at different bioclimatic zones clearly indicates that temperature at higher elevations is increasing significantly more than at lower elevations. In lower tropical bioclimatic zone (LTBZ), upper tropical bioclimatic zone (UTBZ), lower subtropical bioclimatic zone (LSBZ), upper subtropical bioclimatic zone (USBZ), and temperate bioclimatic zone (TBZ), the average temperature increased by $0.022,0.030,0.036,0.042$ and $0.051{ }^{\circ} \mathrm{C} /$ year, respectively. The decade level temperature scenario revealed that the hottest decade was from 1999-2009 and average decade level increases of temperature at different bioclimatic zones ranges from 0.2 to $0.27^{\circ} \mathrm{C} /$ decade. The average temperature and precipitation was found clearly different from one bioclimatic zone to other. This is the first time that bioclimatic zone level precipitation and temperature trends have been analyzed for the CHAL. The rate of additional temperature rise at higher altitudes compared to lower elevations meets the requirements to mitigate climate change in different bioclimatic zones in a different ways. This information would be fundamental to safeguarding vulnerable communities, ecosystem and relevant climate-sensitive sectors from the impact of climate change through formulation of sector-wise climate change adaptation strategies and improving the livelihood of rural communities.
\end{abstract}

Keywords: climate change; lapse rate; precipitation; temperature; trend

\section{Introduction}

Elevation-dependent warming is higher in the Himalayas than any other part of the world $[1,2]$. Globally, the average yearly temperature is increasing by $0.02{ }^{\circ} \mathrm{C}[3]$, but the average maximum yearly 
temperature of Nepal has increased by $0.056{ }^{\circ} \mathrm{C}$ [2],varying in different areas and bioclimatic zones [4]. This indicates that the impact of climate change is severe and more rapid in both the upland and lowland areas of Nepal [5], which could lead to several erratic problems for livelihoods [6], ecosystem processes, biodiversity, and natural resources in general. Climate change is very likely to strongly impact the hydrological cycle, which is predicted to alter rainfall patterns and intensity as well as the frequency of extreme precipitation. Extreme precipitation is considered a trigger for mountain hazards which could threaten agricultural production and the livelihoods of millions of people.

The Chitwan-Annapurna Landscape (CHAL) area in Central Nepal extends from $164 \mathrm{~m}$ to $8091 \mathrm{~m}$ altitudes within a short north-south distance of about $185 \mathrm{~km}$. It covers $32,090 \mathrm{~km}^{2}$, encompassing 19 political districts that cover $22 \%$ of the land in Nepal. It is known that altitude and aspect along the latitude create a wide range of climatic conditions and that CHAL also features almost all types of bio-climate-from tropical to alpine-which makes it an appropriate landscape for climatic study. The climate change analysis and trend information would be useful for biodiversity analysis, biological invasion, natural disaster, and vulnerability and impact studies. Climate change and spread of invasive alien species are major drivers of change in many localities. The interactions and impacts of these and other parameters are often local, specific to the bioclimatic zones in the context of landscape as well as socio-economic and cultural environment. CHAL is a unique landscape in term of environmental, socioeconomic, cultural and livelihood settings. It includes biodiversity rich and provides innumerable ecosystem services to millions of Nepalese people and outsides.

The Nepalese government has prioritized climate change adaptation as an elemental tool to safeguard vulnerable communities, ecosystems and relevant climate sensitive sectors from the impact of climate change [5]. To formulate the adaptation plan at different bioclimatic zones an empirical data on trends of climatic parameter (temperature and precipitation) is crucial. Some of the temperature trends study for a localized place show that warming at higher elevations is more than lower altitudes [2], however temperature and precipitation trend analyses along the different bioclimatic zones in CHAL remain to be documented.

Since 1993, numerous analyses of climatic trends at the national and regional levels have been conducted in Nepal [2,7-20]. Most of these studies have been conducted thorough analyses of selected meteorological stations in Nepal and adjoining regions. However, systematic climatic trends from a complete set of meteorological stations at different bioclimatic zones of a landscape level have not been studied. Due to the topographic variation and orographic effects, the average temperature and precipitation assessment is a challenge in a region like CHAL. Simply averaging the data from stations at different altitudes cannot distinguish variations in trends among bioclimatic zones.

This study fulfils a gap in knowledge of the rate of warming in different elevation levels within CHAL by: (i) analyzing the trends of temperature and precipitation in the different bioclimatic zones, (ii) examining decade interval temperature and precipitation climate change patterns in the different bioclimatic zones, and (iii) determining the average temperature, precipitation, and lapse rate of temperature and precipitation in different bioclimatic zones of the area.

\section{Materials and Methods}

\subsection{Study Area}

The study area is the Chitwan Annapurna Landscape (CHAL), located in central Nepal between $27^{\circ} 35^{\prime}$ and $29^{\circ} 33^{\prime} \mathrm{N}$ latitude and $82^{\circ} 88^{\prime}$ and $85^{\circ} 80^{\prime}$ E longitude [21]. The CHAL includes all or part of 19 districts (Mustang, Manang, Gorkha, Rasuwa, Nuwakot, Dhading, Lamjung, Tanahu, Syangja, Kaski, Palpa, Parbat, Baglung, Myagdi, Gulmi, Arghkhachi, Makwanpur, Chitwan and Nawalparasi, Figure 1). Based on altitude, topography, and climate, Nepal is generally divided into Terai (59-200 m), Siwaliks (200-1500 m), middle mountains (1000-2500 m), high mountains (2200-4000 m), and high Himalayas (>4000 masl). In this study, CHAL is categorized into seven bioclimatic zones [22,23] with slight modification, to evaluate the climatic trends: lower tropical bioclimatic zone $(<500 \mathrm{~m}$, 
LTBZ), upper tropical bioclimatic zone (500-1000 m, UTBZ), lower subtropical bioclimatic zone (1000-1500 m, LSBZ), upper subtropical bioclimatic zone (1500-2000 m, USBZ), temperate bioclimatic zone (TBZ), lower sub-alpine bioclimatic zone (3000-3500 m, LABZ) and upper sub-alpine bioclimatic zone (>3500 $\mathrm{m}$ asl, ABZ).

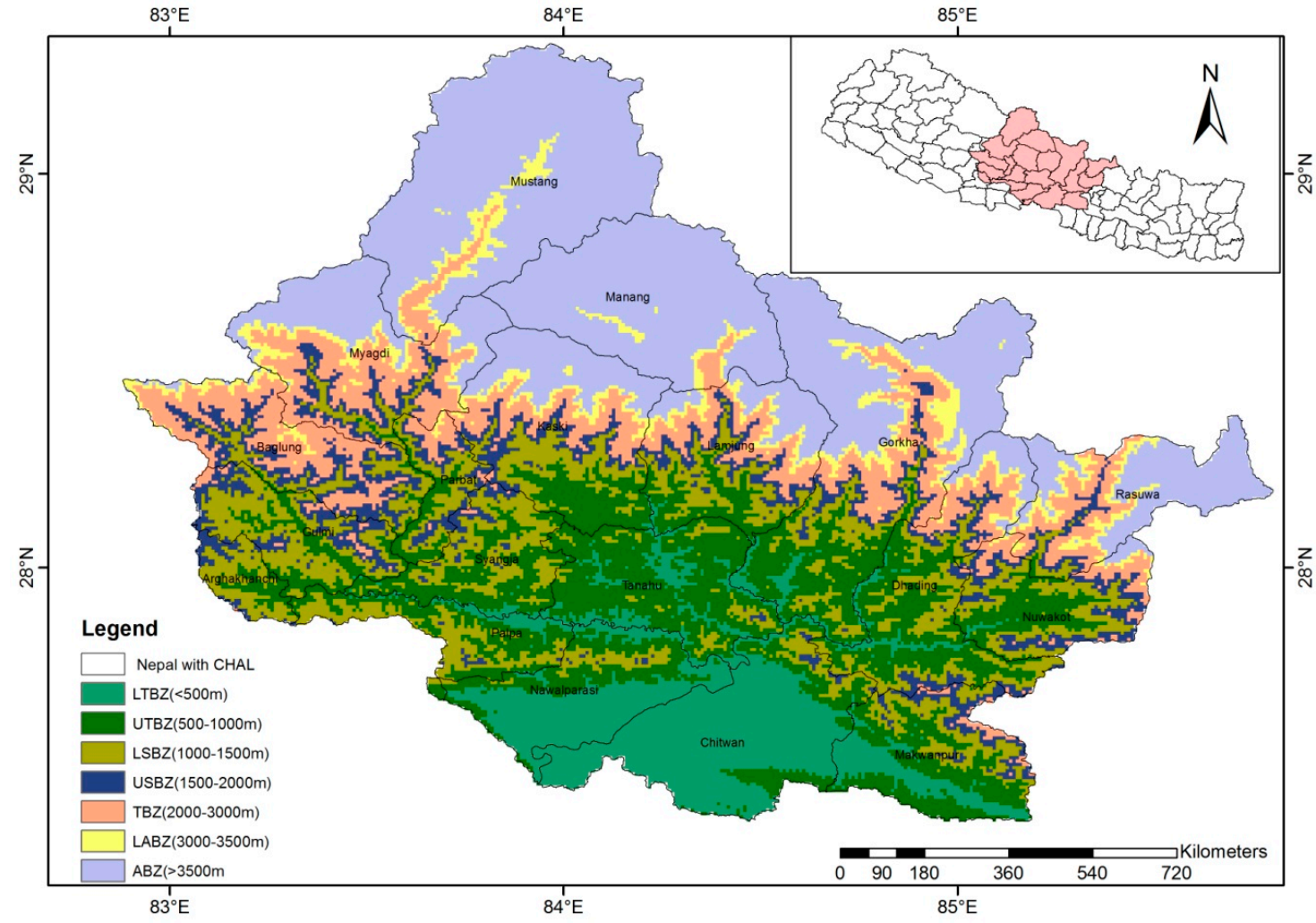

Figure 1. Map of CHAL area with different bioclimatic zones.

A wide range of climatic conditions exist in $\mathrm{CHAL}$, including the tropical humid climate in the lowlands of the Chitwan and Nawalparasi districts, the alpine one in the high mountains and the cold dry climate in the trans-Himalaya in parts of Mustang and Manang districts. The mean temperature of Terai/Siwalik is more than $25^{\circ} \mathrm{C}$, about $20^{\circ} \mathrm{C}$ in the middle hills, and in between $10{ }^{\circ} \mathrm{C}$ to $20^{\circ} \mathrm{C}$ in the high mountains [24]. The average annual rainfall ranges from $165 \mathrm{~mm}$ at Lomanthang (Mustang) in the northern part to $5244 \mathrm{~mm}$ at Lumle (the highest rainfall in the country) in the mid-hills [2]. Orographic effects cause high spatial variation in precipitation in different zones of the landscape. Nearly $78 \%$ of the total annual precipitation occurs during the monsoon season between June and September [16]. Occasional winter rainfall is common, including brief rainfall in the Siwalik and mid-hills and snowfall is common in the high altitude regions.

The LTBZ lies below $500 \mathrm{~m}$ and experiences a tropical climate with dry winters and hot summers, a mean annual temperature is about $25{ }^{\circ} \mathrm{C}$ [24]. It covers major parts of the Terai (Chitwan and Nawalparasi) districts in CHAL. This is dominated by a tropical type of vegetation, mostly sal (Shorea robusta) forests. UTBZ, which covers a major part of the Churia region and has a tropical type of climate, a mean annual average temperature of about $22{ }^{\circ} \mathrm{C}$ [24], covers parts of the Chitwan and Nawalparasi districts and the low lying riverine valleys of the Tanahu, Palpa, Syangja, Arghakhanchi and Dhading districts. The vegetation of UTBZ is a mix of Shorea robusta, Terminalia species, Acacia catechu and Dalbergia sisoo.

LSBZ experiences a subtropical type of climate and covers the lower parts of the mid-hills, including large valleys like Pokhara within CHAL. The average annual mean temperature is about $20^{\circ} \mathrm{C}$ [24]. This region is dominated by Castanopsis indica and Schima wallichii forests, however, depending on the 
altitude and slope of the mountains, forest is replaced by Pinus ruxburgii and Alnus nepalensis species. USBZ also experiences a subtropical type of climate with a maximum rainfall of about $5244 \mathrm{~mm}$ per year at Lumle and an average mean temperature is about $18^{\circ} \mathrm{C}$ [24]. Subtropical broad-leaved forest is the main vegetation in this zone, which produces an important part of the non-timber forest products (NTFPs ) in Nepal.

TBZ covers the main part of the mid-hills, with temperate climate of about $13^{\circ} \mathrm{C}$ average annual temperature. Temperate forests are mainly comprised of lower temperate mixed broad-leaved forests dominated by Quercus lamellosa, Castanopsis tribuloides, and Lauraceae species and upper temperate broad-leaved forests of Quercus semecarpifolia, Acer species, and Rhododendron species

LABZ extends from 3000 to $3500 \mathrm{~m}$ altitudes with a subalpine climate. It covers the major part of the Annapurna conservation area, the largest conservation area with high endemism in Nepal. The subalpine forest mainly comprises Abies spectabilis, Betula utilis, and Rhododendron species. ABZ includes a broad area of high mountains including the cold and dry Trans-Himalayan region of Manang and Mustang districts where the high peaks exceed $8000 \mathrm{~m}$. Subalpine vegetation exists up to $4000 \mathrm{~m}$ and alpine scrub and meadows occur up to the tree lines

\subsection{Climate Analysis}

Daily precipitation and temperature data for all available weather stations in CHAL were procured from the Department of Hydrology and Meteorology (DHM), Government of Nepal. There are 81 precipitation and 32 temperature stations that measure rainfall and temperature within CHAL (Table 1). However, time series data (1970-2019) of daily temperature and rainfall of only 52 precipitation and 26 temperature stations were used in this analysis due to the presence of complete data sets. The stations with incomplete data set were omitted in analysis. The total number of stations in CHAL with complete data set (functional stations) and with incomplete data set are presented in Table 1. The distribution scenarios of functional stations used to depict inferences along different bioclimatic zones are presented in Figures 2 and 3. The station details, including the data available date, are presented in Appendices A and B. The rainfall and temperature trends were calculated in spatial (seven bioclimatic zones based upon altitude, climate, and vegetation) and temporal (annual and decade) scales.

Table 1. Total number of precipitation and temperature stations in each bioclimatic zone in CHAL. Numbers in parentheses indicate stations having complete data sets.

\begin{tabular}{ccc}
\hline Bioclimatic Zones & Precipitation Stations & Temperature Stations \\
\hline LTBZ $(<500 \mathrm{~m})$ & $14(11)$ & $6(5)$ \\
UTBZ $(500-1000 \mathrm{~m})$ & $16(11)$ & $10(8)$ \\
LSBZ $(1000-1500 \mathrm{~m})$ & $16(10)$ & $4(4)$ \\
USBZ $(1500-2000 \mathrm{~m})$ & $14(8)$ & $5(4)$ \\
TBZ $(2000-3000 \mathrm{~m})$ & $10(7)$ & $7(5)$ \\
LABZ $(3000-3500 \mathrm{~m})$ & $3(2)$ & - \\
ABZ $(>3500 \mathrm{~m})$ & $8(3)$ & - \\
Total & $81(52)$ & $32(26)$ \\
\hline
\end{tabular}




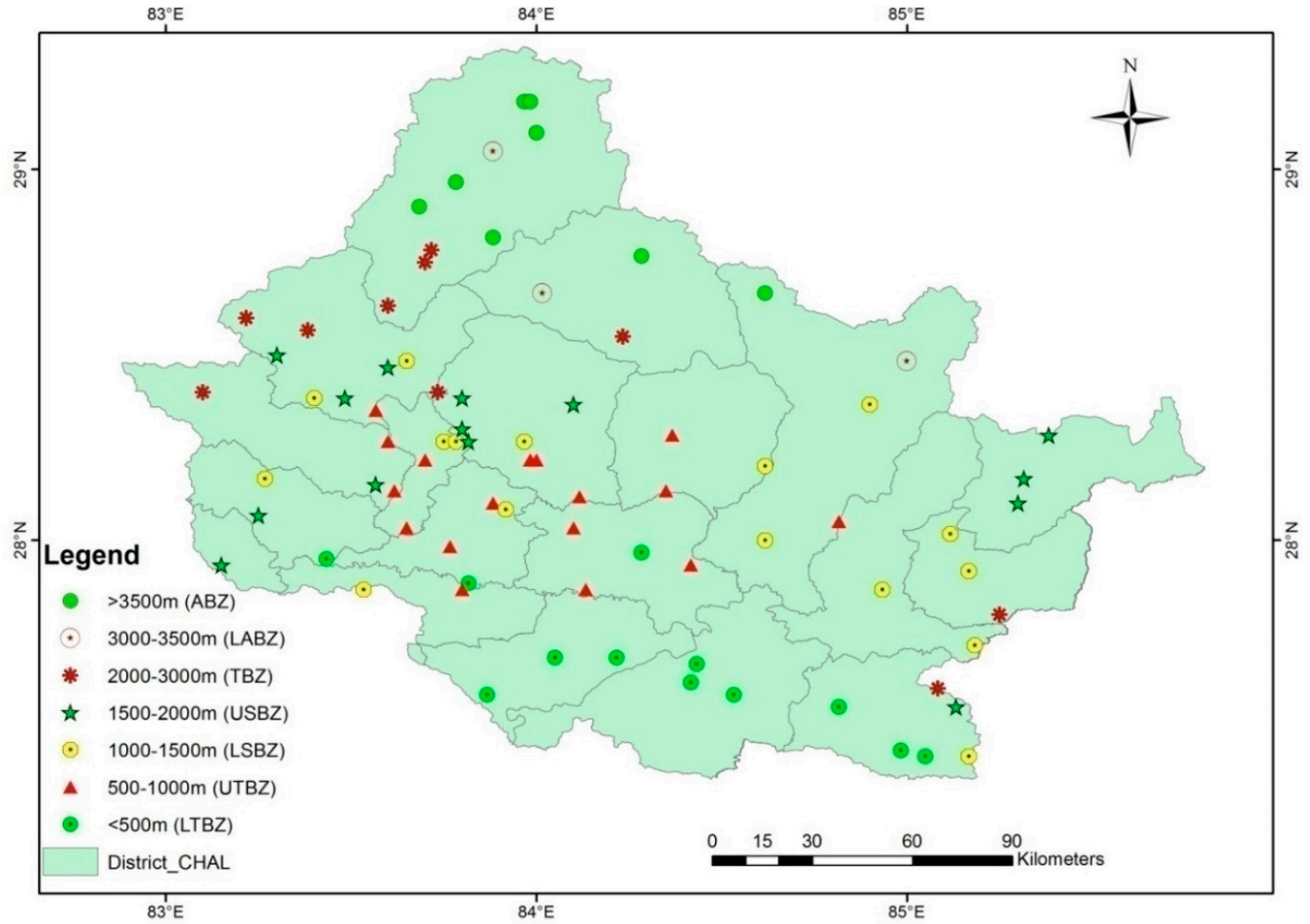

Figure 2. Stations recording precipitation at different bioclimatic zones in CHAL.

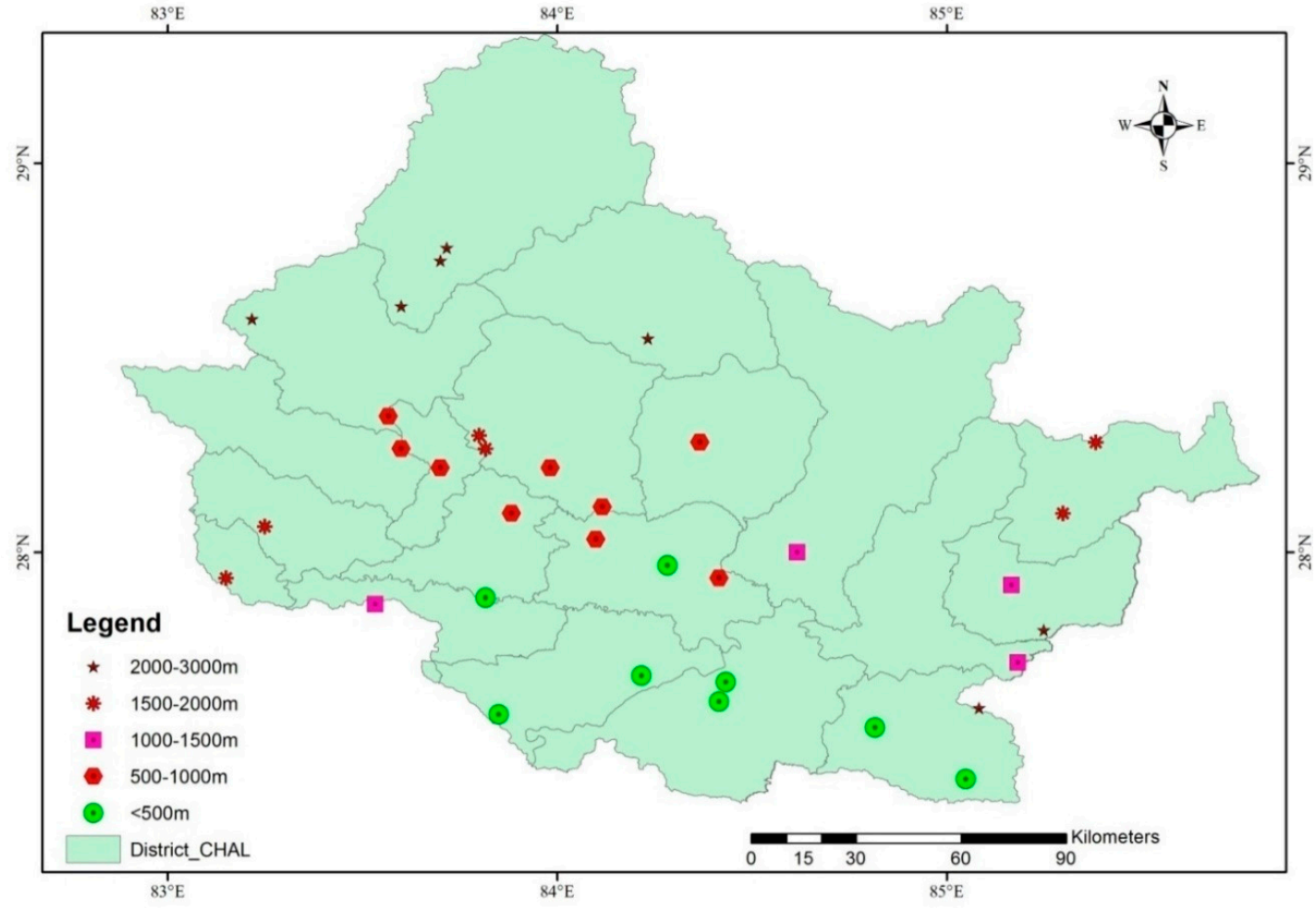

Figure 3. Temperature stations at different bioclimatic zones in CHAL.

The average temperatures of individual stations averaged and the average sum of precipitation from all stations in each bioclimatic zone was calculated. The temperature was analyzed only from LTBZ to TBZ in this study. Although two climatological stations, Jomsom and Thakmarpha (station Id 
601 and 604), lie in between 2500 and $3000 \mathrm{~m}$ altitude in Mustang district of CHAL, the data of these stations cannot represent the temperature of all bioclimatic zones in upper temperate regions. Mustang lies within the Trans-Himalayan region, i.e., a rain shadow area. Therefore, stations of lower temperate and upper temperate bioclimatic zones were merged and averaged to calculate the trend.

\subsection{Data Management}

The stations level data were checked using the Microsoft Excel 2010 software to determine any odd and unusual patterns. The station data that showed outliers and unusual values were corrected for individual stations by replacing them with the average of the value from the previous day and the next day [2]. If there is an outlier or missing data for about a month or more, that particular year is omitted from the analysis.

\subsection{Trend Analysis}

A Mann-Kendall test and Sen's slope methods were used to analyze the climatic trend, magnitude, significance of temperature, and precipitation data in the bioclimatic zones. The Mann-Kendall test is a non-parametric tool and one of the best methods to analyze the presence and significance of monotonic positive or negative trend in time series climatic data $[2,25,26]$. Existence of positive or negative trend among the considered climatic variables was determined by using Mann-Kendall trend test, its quantification was done by using Sen's slope method, and significance by Mann-Kendall Methods in R package version 3.4.4 [27]. The Mann-Kendall method of significance test uses the hypothesis testing approach. In the testing mechanism null hypothesis $\left(\mathrm{H}_{\mathrm{o}}\right)$ there is no monotonic trend in climatic data, and with alternative hypothesis $\left(\mathrm{H}_{1}\right)$, there is a monotonic trend in climatic data at significant level. Significance tests at 0.05 confidence levels were used.

\subsection{Lapse Rate of Temperature and Precipitation}

The lapse rate of temperature and precipitation in different bioclimatic zones along altitudinal gradient in CHAL were calculated following [28,29], with slight modifications. The lapse rate of precipitation was derived by analyzing annual average precipitation sums of the stations lying in each bioclimatic zone by using the following equation:

$$
\operatorname{PPtLR}=\frac{\mathrm{P}_{1}-\mathrm{P}_{2}}{\mathrm{Z}_{1}-\mathrm{Z}_{2}}
$$

where PPt LR is the precipitation lapse rate, $\mathrm{P}_{1}$ and $\mathrm{P}_{2}$ are the precipitation sums of the highest and lowest bioclimatic zones (in $\mathrm{mm}$ ) and $Z_{1}$ and $Z_{2}$ are their respective elevations of higher and lower bioclimatic zones. The value of $Z_{1}-Z_{2}$ considered 1 because our calculation is converted into $1 \mathrm{~km}$ along elevation change.

All temperature data were aggregated into yearly values for the period of 50 years. Temperature lapse rates were calculated through temperature difference between two successive bioclimatic zones i.e., temperature-elevation space [28]. Average temperature is normally assumed to decrease linearly with increasing elevation in CHAL, so Temp LR was calculated as:

$$
\operatorname{TempLR}=\frac{\mathrm{T}_{1}-\mathrm{T}_{2}}{\mathrm{Z}_{1}-\mathrm{Z}_{2}}
$$

where Temp LR is Temperature lapse rate, $T_{1}$ and $T_{2}$ are the yearly average temperatures of the highest and lowest temperature in each bioclimatic zone $\left({ }^{\circ} \mathrm{C}\right)$, and $\mathrm{Z}_{1}$ and $\mathrm{Z}_{2}$ are their average elevations $(\mathrm{m})$. We calculated the lapse rates based on the strong relationship between ambient air temperature and elevation [28-30]. 


\section{Result}

\subsection{Annual Trend of Precipitation}

A mixed pattern of precipitation in different bioclimatic zones was noted in CHAL. Out of seven bioclimatic zones, four zones showed decreasing precipitation and three zones showed an increasing trend (Table 2). Except for UTBZ and LSBZ, the trend was statistically significant in these bioclimatic zones. At LTBZ $(<500 \mathrm{~m})$, the average precipitation significantly decreased at the rate of $1.8 \mathrm{~mm} /$ year. In UTBZ, the precipitation decreased at the rate of $1.98 \mathrm{~mm} /$ year. Precipitation in USBZ had a yearly increase of $0.45 \mathrm{~mm}$, but at USBZ a decreasing rate of $2.06 \mathrm{~mm} /$ year (Table 3 and Figure 4 ).

Table 2. Decade wise average precipitation ( $\mathrm{mm}$ ) trend in different bioclimatic zones in CHAL.

\begin{tabular}{|c|c|c|c|c|c|c|c|c|}
\hline \multirow[b]{2}{*}{ Bioclimatic Zones } & \multirow[b]{2}{*}{ 1970-1979 } & \multirow[b]{2}{*}{ 1980-1989 } & \multirow[b]{2}{*}{ 1990-1999 } & \multirow[b]{2}{*}{ 2000-2009 } & \multirow[b]{2}{*}{ 2010-2019 } & \multicolumn{3}{|c|}{ Trends between 1970-2019 } \\
\hline & & & & & & $\begin{array}{l}\text { Sen's Slope } \\
\text { Per Year }\end{array}$ & $\begin{array}{l}p \text { Value (Mann- } \\
\text { Kendall Test) }\end{array}$ & Significance \\
\hline LTBZ & 1964.4 & 2030.5 & 2022.3 & 2169.3 & 1823.6 & -1.8 & 0.029 & No \\
\hline UTBZ & 2620.8 & 2604.6 & 2665.7 & 2677.8 & 2496.3 & -1.98 & 0.47 & No \\
\hline LSBZ & 2145.8 & 2216.0 & 2362.1 & 2242.8 & 2152.8 & 0.45 & 0.89 & No \\
\hline USBZ & 3222.5 & 3422.9 & 3066.9 & 3105.5 & 2913.79 & -2.06 & 0.03 & Yes \\
\hline TBZ & 1230.2 & 1558.1 & 1519.65 & 1498.75 & 1429.25 & 1.81 & 0.002 & Yes \\
\hline LABZ & 886.2 & 854.8 & 992.1 & 971.1 & 1056.2 & 1.28 & 0.0001 & Yes \\
\hline $\mathrm{ABZ}$ & 366.8 & 444.3 & 351.1 & 298.4 & 348.0 & -1.80 & 0.05 & Yes \\
\hline
\end{tabular}

Table 3. Average temperature trend (1970-2019) in different bioclimatic zones in CHAL.

\begin{tabular}{cccc}
\hline Bioclimatic Zones & Sen's Slope & $\boldsymbol{p}$ Value (Mann-Kendall Test) & Significance \\
\hline LTBZ & 0.022 & $<0.001$ & Yes \\
UTBZ & 0.030 & $<0.00001$ & Yes \\
LSBZ & 0.036 & $<0.0001$ & Yes \\
USBZ & 0.042 & $<0.00001$ & Yes \\
TBZ & 0.051 & $<0.0001$ & Yes \\
\hline
\end{tabular}

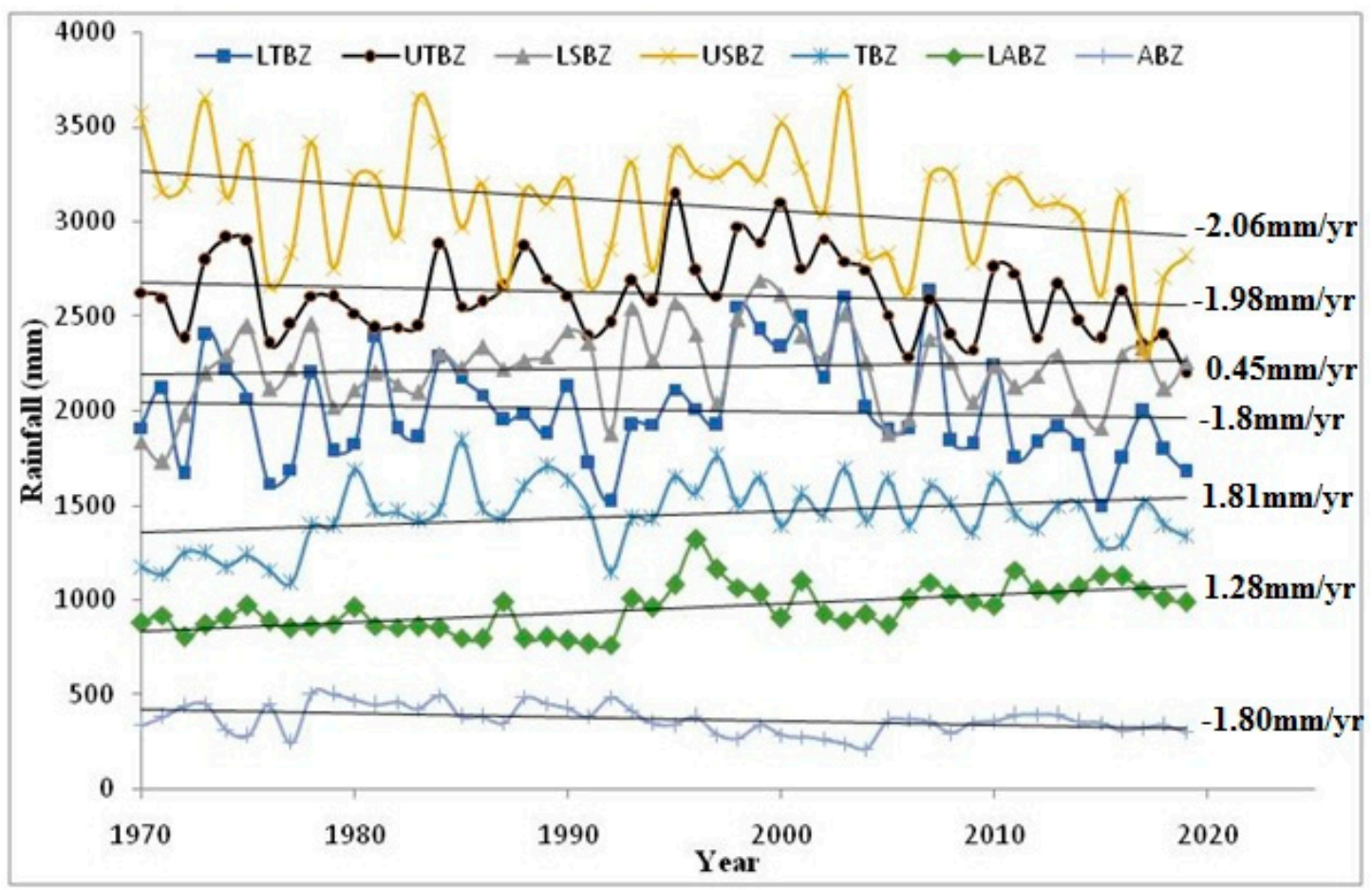

Figure 4. Average annual rainfall trends in different bioclimatic zones in CHAL. 
Above $2000 \mathrm{~m}$ elevation, the precipitation showed an increasing trend up to $3500 \mathrm{~m}$ and then decreasing again. At TBZ (2000-3000 m), the precipitation increased at the rate of $1.81 \mathrm{~mm} / \mathrm{year}$ and in LABZ (3000-3500 m) it also increased at the rate of $1.28 \mathrm{~mm} /$ year. At ABZ ( $>3500 \mathrm{~m})$, precipitation had a decreasing trend at the rate of $1.80 \mathrm{~mm} /$ year (Table 3 and Figure 4).

\subsection{Precipitation Trends in Different Decades}

The average decade rainfall in the bioclimatic zones in CHAL was analyzed. In general, precipitation in all bioclimatic zones increased until 2000AD, but decreased after. In UTBZ, the average rainfall increased from 1970-1979 to 1980-1990 and again showed a decreasing and increasing pattern. In the last decade (2010-2019), the average rainfall was found to be decreasing from preceding decades. From Sen's slope value, the rainfall was found to be decreasing at the rate of $19.8 \mathrm{~mm}$ per decade.

USBZ received the maximum average rainfall in CHAL (Figure 5); however, its overall trend shows that average precipitation was decreasing at the rate of $20.6 \mathrm{~mm} /$ decade (Table 2).

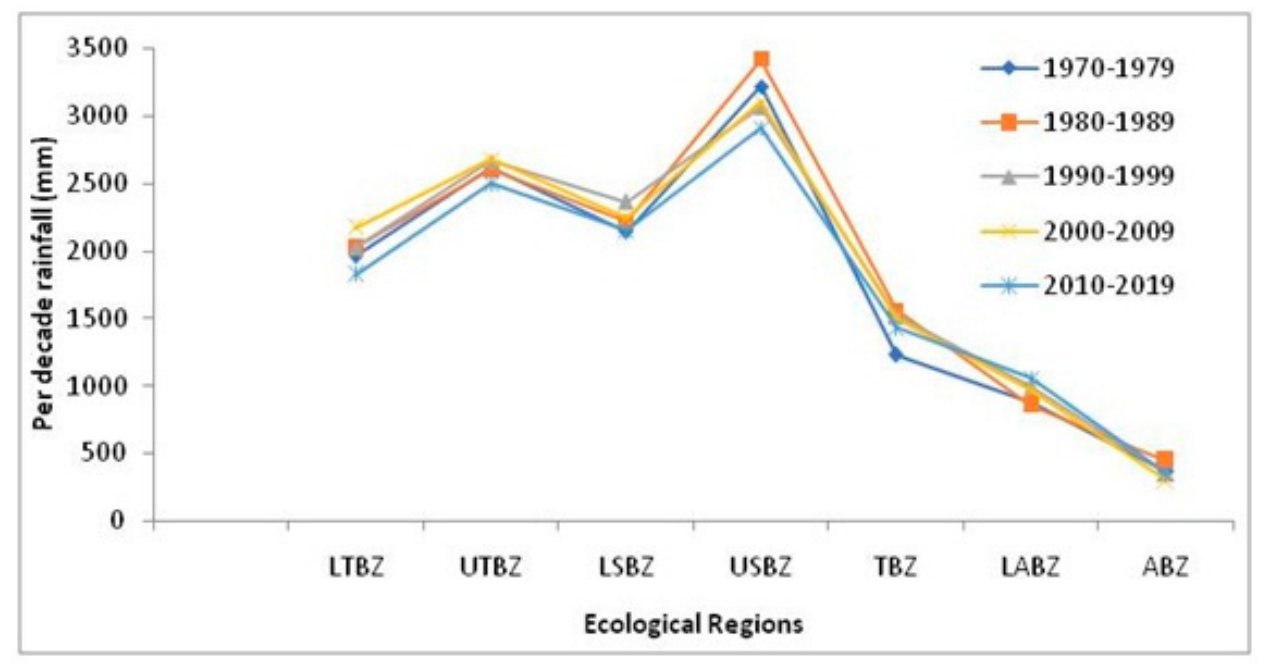

Figure 5. Decade-wise precipitation trends along different bioclimatic zones in CHAL.

In TBZ, from the first (1970-1979) to the second decade (1980-1989), the rainfall trend was found to be increasing and decreasing thereafter. However, overall decade level trend analysis showed increasing rainfall at the rate of $18.1 \mathrm{~mm} /$ decade. Similarly, no particular trend was seen in LABZ, but the average decade rainfall was found to be increasing at the rate of $12.8 \mathrm{~mm} /$ decade.

\subsection{Annual Trend of Temperature}

The average temperature increased by $0.022{ }^{\circ} \mathrm{C} /$ year during 1970 to 2019 in LTBZ. However, in UTBZ, LSBZ, USBZ, and TBZ, the average annual temperature increased by $0.030,0.036,0.042$, and $0.051^{\circ} \mathrm{C} /$ year, respectively. This result clearly indicates that the temperature at higher elevations has been increasing significantly more than at lower elevations (Table 3 and Figure 6). Although the average temperature increased in all bioclimatic zones, the average annual temperature increase rate at higher elevations was high. 


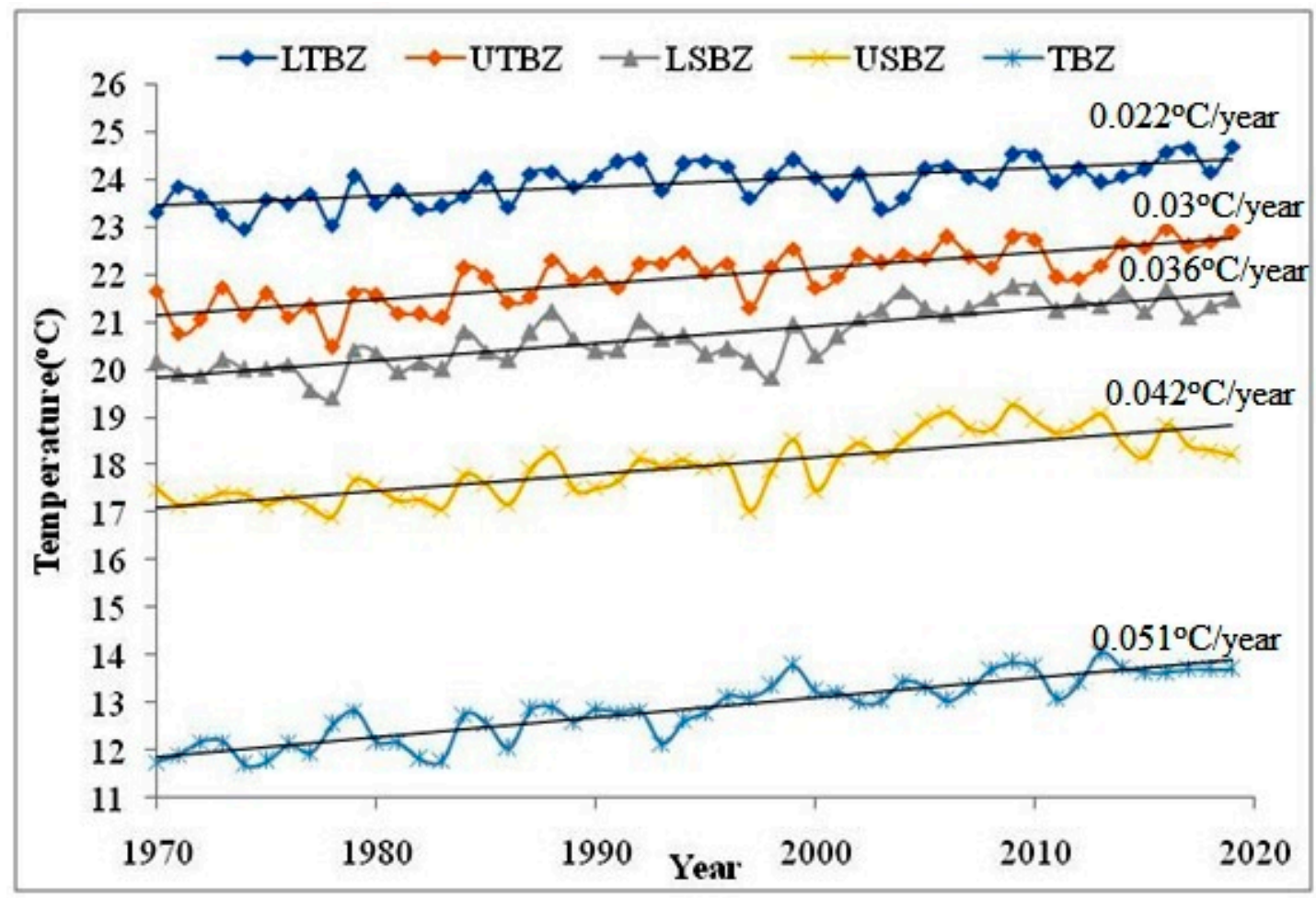

Figure 6. Average temperature trends in different bioclimatic zones of CHAL (1970-2019).

\subsection{Temperatures in Different Decades}

The average temperature in every bioclimatic zone of CHAL has been increasing over the past five decades (Table 4). On average, at a rate of $0.2^{\circ} \mathrm{C} /$ decade, the temperature significantly increased at LTBZ of CHAL. At LTBZ, from 1989-1999, the highest average temperature increase was $0.27^{\circ} \mathrm{C} /$ decade. From 1979-1989, the average temperature rose by $0.26^{\circ} \mathrm{C} /$ decade, but during the last two decades it experienced a slightly low temperature gain (Table 4). Similarly, 1999-2009 was a comparatively hotter decade in higher altitudes above $1000 \mathrm{~m}$ (Table 4).

Table 4. Increased average temperature $\left({ }^{\circ} \mathrm{C}\right)$ per decade in different bioclimatic zones of CHAL since 1979.

\begin{tabular}{ccccccc}
\hline \multirow{2}{*}{ Bioclimatic Zones } & $\mathbf{1 9 7 9 - 1 9 8 9}$ & $\mathbf{1 9 8 9 - 1 9 9 9}$ & $\mathbf{1 9 9 9 - 2 0 0 9}$ & $\mathbf{2 0 0 9 - 2 0 1 9}$ & \multicolumn{2}{c}{$\mathbf{1 9 7 9 - 2 0 1 9}$} \\
\cline { 5 - 7 } & & & & & Sen's Slope & Significance \\
\hline LTBZ & 0.26 & 0.27 & 0.16 & 0.19 & 0.022 & Yes \\
UTBZ & 0.28 & 0.28 & 0.33 & 0.32 & 0.030 & Yes \\
LSBZ & 0.17 & 0.39 & 0.44 & 0.42 & 0.036 & Yes \\
USBZ & 0.36 & 0.39 & 0.44 & 0.47 & 0.042 & Yes \\
TBZ & 0.48 & 0.51 & 0.56 & 0.52 & 0.051 & Yes \\
\hline
\end{tabular}

\subsection{Average Annual Temperature and Precipitation}

The average temperature and precipitation values of all stations in each bioclimatic zone have been analyzed for 1970-2019(Table 5). The results show 24.1, 21.8, 19.7, 17.5, and $13.3^{\circ} \mathrm{C}$ average annual temperatures at LTBZ, UTBZ, LSBZ, USBZ, and TBZ, respectively, in CHAL. 
Table 5. Lapse rate and average temperature and precipitation along different bioclimatic zones in CHAL.

\begin{tabular}{|c|c|c|c|c|c|c|}
\hline Bioclimatic Zones & $\operatorname{AAT}\left({ }^{\circ} \mathrm{C}\right)$ & $\begin{array}{c}\text { TLR } \\
\left({ }^{\circ} \mathrm{C} / 500 \mathrm{~m}\right)\end{array}$ & TLR $\left({ }^{\circ} \mathrm{C} / \mathrm{km}\right)$ & $\operatorname{ANR}(\mathrm{mm})$ & $\begin{array}{c}\text { PLR } \\
(\mathrm{mm} / 500 \mathrm{~m})\end{array}$ & $\begin{array}{c}\text { PLR } \\
(\mathrm{mm} / \mathrm{km})\end{array}$ \\
\hline $\begin{array}{c}\text { Lower tropical } \\
\text { bioclimatic zone }(<500 \mathrm{~m})\end{array}$ & 24.1 & & - & 2002.1 & & - \\
\hline $\begin{array}{l}\text { Upper tropical bioclimatic } \\
\text { zone }(500-1000 \mathrm{~m})\end{array}$ & 21.8 & -2.3 & -4.6 & 2613.1 & 611 & 1222 \\
\hline $\begin{array}{l}\text { Lower subtropical } \\
\text { bioclimatic zone } \\
(1000-1500 \mathrm{~m})\end{array}$ & 19.7 & -2.1 & -4.2 & 2223.9 & -389.2 & -778.4 \\
\hline $\begin{array}{l}\text { Upper subtropical } \\
\text { bioclimatic zone } \\
(1500-2000 \mathrm{~m})\end{array}$ & 17.5 & -2.2 & -4.4 & 3146.4 & 922.5 & 1845 \\
\hline $\begin{array}{l}\text { Temperate bio- climatic } \\
\text { zone }(2000-3000 \mathrm{~m}) \\
\text { Lower subalpine }\end{array}$ & 13.3 & -2.2 & -4.4 & 1447.2 & -849.6 & -1699.2 \\
\hline $\begin{array}{c}\text { bioclimatic zone } \\
(3000-3500 \mathrm{~m})\end{array}$ & & & & 952.1 & -495.1 & -990.2 \\
\hline $\begin{array}{l}\text { Alpine bioclimatic zone } \\
\qquad(>3500 \mathrm{~m})\end{array}$ & & & & 361.7 & -590.4 & -1180.8 \\
\hline
\end{tabular}

Similarly, average annual precipitation in LTBZ, UTBZ, LSBZ, USBZ, TBZ, LBZ, and ABZ was 2002.1, 2613.1, 2223.9, 3146.9, 1447.2, 952.1, and $361.7 \mathrm{~mm} /$ year, respectively. This result indicates that with increasing altitude from LTBZ to UTBZ, annual average precipitation increased, but in other BZ the precipitation successively decreased (Table 5).

\subsection{Lapse Rate of Temperature and Precipitation Lapse Rate}

The temperature lapse rate showed 2.1 to $2.3^{\circ} \mathrm{C}$ decreases with every $500 \mathrm{~m}$ altitude increase along different bioclimatic zones in CHAL (Table 5). This implies that every one-kilometer that altitude rises, the temperature decreases by 4.2 to $4.6^{\circ} \mathrm{C} / \mathrm{km}$ in CHAL. Precipitation lapse rate analysis in CHAL does not show any specific pattern. However, greater PLA was found above from $2000 \mathrm{~m}$ elevation (Table 5).

\section{Discussion}

A mixed pattern of precipitation in different bioclimatic zones is in congruence with the precipitation pattern for the whole of Nepal [31]. Previous work in different parts of CHAL were localized to districts or whole regions involving small scale analysis based on some meteorological stations of Lamjung [32], Syangja [33], and other districts [2]. According to Poudel and Shaw [32], annual precipitation was increasing in the Khudi $(855 \mathrm{~m})$ and Kunchha $(823 \mathrm{~m})$ stations of Lamjung district at the rate of $0.063 \mathrm{~mm} /$ year and $4.42 \mathrm{~mm} /$ year, respectively. However, at the Gharedhunga $(1120 \mathrm{~m})$ station, in the same district over the course of 32 years (1980-2012), there was a decreasing trend at the rate of $3.48 \mathrm{~mm} /$ year within CHAL. Our findings in general conclude that for the whole CHAL, annual average precipitation varies because the precipitation amounts are varying in different years.

According to DHM [2], normal annual precipitation at a district level in CHAL showed that Mustang, a trans-Himalaya region, receives the lowest rainfall $(<400 \mathrm{~mm})$, whereas Kaski, Parbat, Tanahu, Lamjung, and Nuwakot receive more than $2000 \mathrm{~mm}$ of annual rain. Similarly, the High Himalayas (>4000 $\mathrm{m}$ ) receive the least amount of rain and the remaining regions receive $1500-2000 \mathrm{~mm}$, which is consistent with the present results. The annual precipitation trend of Nepal along different physiographic regions showed inconsistency. According to [2], in Terai, the annual average rainfall was found to be increasing at the rate of $0.49 \mathrm{~mm} /$ year, but Siwalik, Mid-mountain, High mountains, and High Himalayas showed decreases at rates of 1.48, 1.58, 3.17 and $1.46 \mathrm{~mm} /$ year, respectively. For the whole of Nepal, total annual precipitation since the 1960s has been decreasing at the rate of $3.7 \mathrm{~mm}$ per year [34]. District wise, annual precipitation trends in CHAL show a different pattern. Among the 19 districts, annual average rainfall significantly decreased in 10 districts and decreased in 
nine districts [2], which is consistent with the present study. There is no previous comparison at the bioclimatic zone level in CHAL.

In Nepal, the average annual rainfall is $1858.6 \mathrm{~mm}$ [35]; however, the spatial pattern of annual rainfall in the country depends on the topography. Altitude further affects rainfall patterns; total annual rainfall increases with altitude up to approximately $3000 \mathrm{~m}$ above sea level and then diminishes at higher elevations [36]. However, in CHAL, average annual rainfall was found to be inconsistently increasing and decreasing from lower to higher altitudes because of mountains blocking the monsoon wind. Seasonal analysis of station-based rainfall pattern in Gandaki river basin (major part of CHAL) revealed a significantly decreasing winter rainfall but increasing monsoon rainfall [16]. The precipitation was found to be significantly increasing in the high mountains of CHAL.

Precipitation in each bioclimatic zone in the mountains depends upon many factors such as topography, strength of moisture-bearing winds and the orientation of the mountain ranges with respect to the prevailing wind direction. Thus, precipitation processes and distribution in a region are influenced by the aforementioned factors, including steep altitudinal contrast [37]. Variation in elevation within a very short distance of about $185 \mathrm{~km}$ creates dissimilarity in precipitation within particular regions in Nepal [31,38]. In this study, we found that the rainfall in LTBZ and UTBZ is decreasing annually, but in LSBZ it is increasing, and again significantly decreasing in USBZ. This unusual pattern of precipitation along different bioclimatic zones of CHAL is therefore due to orography and the spatial arrangement of topographic gradients, which control the precipitation patterns [37]. These spatial arrangements of topographic gradients, wind direction, aspects and slopes of mountain may alter consistency in precipitation along different ecological zones within a short distance in CHAL.

In the higher elevations above $2000 \mathrm{~m}$, annual precipitation was found to be much lower than precipitation at lower elevations. Increases in annual precipitation from LTBZ to higher elevations up to $2000 \mathrm{~m}$ at USBZ, and decreases in precipitation above TBZ were well noted. The highest annual rainfall was found in USBZ in CHAL. The Lumle station in CHAL received the highest amount of annual precipitation in Nepal of about $5500 \mathrm{~mm}[35,39]$ as it lies on the windward side of the Annapurna-Machhapuchhre mountain range. The lowest precipitation site was recorded in Upper Mustang Dhiee, Lomanthang area of Mustang district within CHAL, with a mean annual precipitation of less than $200 \mathrm{~mm}$. Both of these highest and lowest precipitation sites of the country are in the Annapurna area of present study site.

According to [15], there are two high monsoonal rainfall zones in Nepal, one around $600 \mathrm{~m}$ and another around $2100 \mathrm{~m}$, with different rain patterns. This record of gradual increasing precipitation from LTBZ to USBZ, with highest at around $2000 \mathrm{~m}$ altitude, may be due to presence of high monsoonal rainfall zones. From the comprehensive precipitation observations in the Annapurna range [40], showed that the annual precipitation gradually increases from lowland and had a strong peak at about $3000 \mathrm{~m}$ altitude, then decreases as elevation increases. However, the present analysis showed that strong peak of precipitation at $2000 \mathrm{~m}$ then decreases as elevation increases in CHAL, which is inconsistent with the results of [40].

According to the precipitation trend analyzed from data of 80 stations in Nepal, most of the Terai area and Western Nepal observe a negative trend [41]. The hills and mountains of Western Nepal and the northern part of Eastern Nepal have a positive trend. Based on data from 1947 to 1993, [42] found that the precipitation trend in the Koshi Basin (Eastern Nepal) showed an increasing trend. The overall average trend for Nepal indicates that the annual average precipitation is decreasing at the rate of $9.8 \mathrm{~mm} /$ decade [5]. Our findings on decade level precipitation trends in different bioclimatic zones of CHAL showed consistency with previous findings from Nepal.

According to [43], the global mean surface temperature has increased on average by $0.8^{\circ} \mathrm{C}$ in the 20th century and by $0.6^{\circ} \mathrm{C}$ from 1975 to 2005 . Reference [9] reported the maximum temperature increased in mountains of Nepal during 1971-1994 by 0.06 to $0.12^{\circ} \mathrm{C} /$ year, while the southern plains increased by less than $0.03{ }^{\circ} \mathrm{C} /$ year, and during $1970-2015$ the maximum temperature increased by 
$0.056^{\circ} \mathrm{C} /$ year in Nepal [2]. In the CHAL, the rise in average temperature was found to be considerably higher than the global average.

At the district level, the highest significant positive trend was observed in Manang district $\left(0.12^{\circ} \mathrm{C} / \mathrm{yr}\right)$ [2]. The average annual temperature increased in Terai $(<200 \mathrm{~m})$, Siwalik $(200-1500 \mathrm{~m})$, Middle mountain (1500-2500 m), High mountain (2200-4000 m), and High Himalayas at the rate of $0.020,0.023,0.031,0.032$, and $0.035^{\circ} \mathrm{C} /$ year, respectively, which is a similar pattern as in the present study. The temperature increase was noted higher in our study than DHM (2017). This speedy warming trend in high elevation zones compared to lower altitudes is due to melting of snow and ice [44] and cold air pooling along local heating by combination of topography and synoptic conditions [45].

In Nepal, the average temperature and precipitation analysis for different bioclimatic zones in particular areas has not been assessed before. However, average temperature and precipitation analysis along different physiographic regions had been done. The range of temperature in Terai and Siwalik, mid-hills, and mountain physiographic regions is $20-25,15-20,10-20,<3-10^{\circ} \mathrm{C}$, respectively $[24,36]$. Reference [20] analyzed the variation in temperature by increasing every two hundred meters altitudes and found that temperature at $<200 \mathrm{~m}$ was $24.8^{\circ} \mathrm{C}$. The temperature at $<3800 \mathrm{~m}$ was $7.8^{\circ} \mathrm{C}$ without any consistency pattern of increasing temperature in between the lowest to higher elevation.

Thus, these reasonable elevation-dependent temperature and precipitation trends vary due to elevation-based differential changes in climate drivers, such as snow/ice cover, clouds, water vapor, aerosols and soil moisture, or differential sensitivities of surface warming due to changes in these drivers at different elevations. However, mountain systems are inherently difficult to understand as a result of their complex topography, which leads to a high level of spatial and temporal variability in their climatic responses [4].

According to [29], the annual average TLR on the southern slope of the central Himalayas is $-5.2^{\circ} \mathrm{C} / \mathrm{km}$, which is -0.4 to $0.8^{\circ} \mathrm{C} / \mathrm{km}$ higher than lapse rate at different bioclimatic zones of CHAL. The lapse rate of temperature depends on surface air temperature on elevation and varies due to different seasonality, interplay of radiation, slope and aspect of the mountains, and several local factors [46].

However, the precipitation lapse rate shows irregular patterns in different bioclimatic zones in CHAL. When altitudes rise from LTBZ to UTBZ, PLR shows positive trends of $611 \mathrm{~mm} / 500 \mathrm{~m}$ elevation i.e. $1222 \mathrm{~mm} / \mathrm{km}$. However, moving upwards from UTBZ to LSBZ, the precipitation lapse rate (PLR) shows negative rate of $778.4 \mathrm{~mm} / \mathrm{km}$, and then again shows the rate of $1845 \mathrm{~mm} / \mathrm{km}$ up to $3000 \mathrm{~m}$. Then, PLR continuously decreases as altitude increases. The rate of decrease is higher at the uppermost elevation (Table 5). This unusual pattern of increasing and decreasing PLR is consistent with [47] in Langtang valley within CHAL. The difference in PLR between different bioclimatic zones may be due to the local effects of topography, slope, and aspects of mountain as well as the direction of wind and many other local factors.

\section{Conclusions}

The geological position of a place plays a crucial role in the distribution of temperature and precipitation. This study elaborates this notion to understand the spatial and temporal patterns of temperature and precipitation and its trends across different bioclimatic zones of CHAL. Annual and decade level precipitation and temperature trend analysis was carried out from time series daily data (1970-2019) obtained from weather stations in seven bioclimatic zones extending from lowland Terai to the higher Himalayas in CHAL. Precipitation and temperature lapse rates and average precipitation and temperature in each bioclimatic zone was also analyzed. A mixed pattern of precipitation in different bioclimatic zones was noted in CHAL. Out of seven bioclimatic zones, four zones showed decreasing and three zones showed increasing precipitation trends. Within the CHAL, the alpine bioclimatic zone gets the lowest amount of precipitation whereas the upper subtropical bioclimatic zone receives the most annual precipitation. However, the precipitation trend at higher altitudes 
showed a greater decrease. Average decade level rainfall in all bioclimatic zones increased until 2000AD, but decreased thereafter.

Bioclimatic zone level trend analysis showed a robust significant positive trend in annual temperature. Annual temperature trends clearly indicated that the temperature at upper elevations has been increasing significantly and more than at lower elevations. The temperature trends showed progressive increases from lower to higher elevations. This clearly indicates a significant increasing temperature on both spatial and temporal scales in CHAL. The temperate climatic zone of CHAL(altitudes in between $2000-3000 \mathrm{~m}$ ) become $0.051{ }^{\circ} \mathrm{C}$ hotter every year but the average temperature increased by $0.022^{\circ} \mathrm{C} /$ year in LTBZ(below $500 \mathrm{~m}$ ). The significant successive annual temperature in UTBZ, LSBZ and USBZ is increasing at the rate of $0.030,0.036$ and $0.042{ }^{\circ} \mathrm{C} /$ year, respectively. The average temperature in every bioclimatic zone of CHAL has been increasing over the past five decades and 1999-2009 was a comparatively hotter decade at higher altitudes above $1000 \mathrm{~m}$. On average, the temperature increased at a rate of $0.2{ }^{\circ} \mathrm{C}$ to $0.27^{\circ} \mathrm{C} /$ decade in different bioclimatic zones in CHAL between 1970-2019.

This average precipitation and temperature study of each bioclimatic zones in CHAL contributes to understanding the variation of spatial patterns of climatic parameters with increasing altitudes. The average temperature and precipitation in lower tropical bioclimatic zone was $24.1^{\circ} \mathrm{C}$ and $2002.1 \mathrm{~mm}$, respectively. The average temperature and precipitation of the upper tropical bioclimatic zone was $21.8^{\circ} \mathrm{C}$ and $2613.1 \mathrm{~mm}$, and the average temperature in LSBZ, USBZ and TBZ was 19.7, 17.5, and $13.6{ }^{\circ} \mathrm{C}$, respectively. This study identified a $2.1-2.3{ }^{\circ} \mathrm{C}$ temperature lapse rate. i.e., a $2.1-2.3{ }^{\circ} \mathrm{C}$ temperature decrease for every $500 \mathrm{~m}$ of altitude increase in CHAL. The average annual precipitation in LSBZ was $2223.9 \mathrm{~mm}$ and $3146.9 \mathrm{~mm}$ in the upper subtropical bioclimatic zones with the highest rainfall in CHAL. TBZ, LBZ, and ABZ receive 1447.2, 952.1, and $361.7 \mathrm{~mm}$ precipitation annually, respectively. These findings of temperature and precipitation trends in every bioclimatic zones might have numerous implications to the local people in each bioclimatic zone. The result should be useful for the planning of mitigation and adaptation strategies for climate change impacts indifferent bioclimatic zone in special ways.

Author Contributions: D.R.L., primary researcher, designed concept collected data, gathering and processing of all data source, and prepared manuscript. P.K.J., M.S., M.L.S. participate in its design, supervised the works and edited the manuscript. R.M. was involved in interpretation of results and funding acquisition. All authors have read and agreed to the published version of the manuscript.

Funding: This work was funded in whole by the United States Agency for International Development (USAID) Bureau of Food Security under the Cooperative Agreement No. AID-OAA-L-15-00001 as a part of Feed the Future Innovation Lab for Integrated Pest Management.

Acknowledgments: Thanks are due to Ram Kailash Prasad Yadav, Head, Central Department of Botany, TU for encouragement. We especially thank to Hari Prasad Pandey, Undersecretary, Ministry of Forests and Environment for guiding our Mann Kendall test and Sen's slope determination in the R package. Thanks are also extended to the Department of Hydrology and Meteorology, Government of Nepal, for providing climatic data and to Sara Hendery for language editing.

Conflicts of Interest: The authors declare no conflict of interest. 


\section{Appendix A}

Table A1. Stations used to analyze the temperature trends in CHAL, 1970-2019.

\begin{tabular}{|c|c|c|c|c|c|c|c|}
\hline Station Name & Station ID & Station Type & District & Latitude & Longitude & Altitude (m) & Data Available \\
\hline \multicolumn{8}{|c|}{ Lower tropical bioclimatic zone $(<500 \mathrm{~m})$} \\
\hline Dumkauli & 706 & Agro-meteorology & Nawalparasi & 28.1 & 84.22 & 154 & 1976 \\
\hline Simari & 728 & Climatology & Nawalparasi & 28.12 & 83.75 & 154 & 1981 \\
\hline Chapakot & 810 & Climatology & Syangja & 27.88 & 83.82 & 460 & 1979 \\
\hline Rampur & 902 & Agro-meteorology & Chitwan & 28.02 & 84.42 & 256 & 1970 \\
\hline Hetauda NFI & 906 & Climatology & Makawanpur & 27.68 & 85.05 & 474 & 1971 \\
\hline \multicolumn{8}{|c|}{ Upper tropical bioclimatic zone (500-1000 m) } \\
\hline Baglung & 605 & Climatology & Baglung & 27.93 & 83.6 & 984 & 1978 \\
\hline Beni bazar & 609 & Climatology & Myagdi & 27.53 & 83.57 & 835 & 1989 \\
\hline Kusma & 614 & Climatology & Parbat & 28.28 & 83.7 & 891 & 1989 \\
\hline Khudi bazar & 802 & Climatology & Lamjung & 28.3 & 84.37 & 823 & 1970 \\
\hline Pokhara airport & 804 & aeronautical & Kaski & 28.03 & 84.0 & 827 & 1970 \\
\hline Syangja & 805 & Climatology & Syangja & 27.62 & 83.88 & 868 & 1976 \\
\hline Malepatan & 811 & Agro-meteorology & Kaski & 27.92 & 84.12 & 856 & 1970 \\
\hline Khairenitar & 815 & Climatology & Tanahu & 28.1 & 84.1 & 500 & 1970 \\
\hline \multicolumn{8}{|c|}{ Lower subtropical bioclimatic zone (1000-1500 m) } \\
\hline Tansen & 702 & Climatology & Palpa & 28.22 & 83.53 & 1067 & 1972 \\
\hline Gorkha & 809 & Agro-meteorology & Gorkha & 28 & 84.62 & 1097 & 1970 \\
\hline Nuwakot & 1004 & Climatology & Nuwakot & 27.93 & 85.02 & 1003 & 1970 \\
\hline Pensayakhola & 1057 & Climatology & Nuwakot & 28.28 & 85.12 & 1240 & 1975 \\
\hline \multicolumn{8}{|c|}{ Upper subtropical bioclimatic zone (1500-2000 m) } \\
\hline Khachikot & 715 & Climatology & Arghakhanchi & 28 & 83.15 & 1760 & 1977 \\
\hline Tamghas & 725 & Climatology & Gulmi & 27.88 & 83.25 & 1530 & 1981 \\
\hline Lumle & 814 & Agro-meteorology & Kaski & 27.8 & 83.8 & 1740 & 1970 \\
\hline Dhunche & 1055 & Climatology & Rasuwa & 28.1 & 85.3 & 1982 & 1989 \\
\hline \multicolumn{8}{|c|}{ Temperate bio climatic zone $(2000-2500 \mathrm{~m})$} \\
\hline Jomsom & 601 & Climatology & Mustang & 27.87 & 83.72 & 2744 & 1970 \\
\hline Thakmarpha & 604 & Agro-meteorology & Mustang & 27.68 & 83.7 & 2566 & 1970 \\
\hline Daman & 905 & Climatology & Makawanpur & 27.87 & 85.08 & 2314 & 1972 \\
\hline Lete & 607 & Climatology & Mustang & 28.07 & 83.6 & 2384 & 1998 \\
\hline Kakani & 1007 & Agro-meteorology & Nuwakot & 28.07 & 85.25 & 2064 & 1972 \\
\hline
\end{tabular}

Source: Department of Hydrology and Meteorology.

\section{Appendix B}

Table A2. Stations used to analyze the precipitation trends in CHAL.

\begin{tabular}{|c|c|c|c|c|c|c|}
\hline Station Name & Station ID & Station Type & District & Latitude & Longitude & Altitude \\
\hline \multicolumn{7}{|c|}{ Lower tropical bioclimatic zone $(<500 \mathrm{~m})$} \\
\hline Ridi bazar & 701 & Precipitation & Gulmi & 27.95 & 83.43 & 442 \\
\hline Beluwa (girwari) & 704 & Precipitation & Nawalparasi & 27.68 & 84.05 & 150 \\
\hline Dumkauli & 706 & Agrometeorology & Nawalparasi & 27.68 & 84.22 & 154 \\
\hline Dumkibas & 710 & Precipitation & Nawalparasi & 27.58 & 83.87 & 164 \\
\hline Chapkot & 810 & Climatology & Syangja & 27.88 & 83.82 & 460 \\
\hline Damauli & 817 & Climatology & Tanahun & 27.97 & 84.28 & 358 \\
\hline Rampur & 902 & Agrometeorology & Chitawan & 27.62 & 84.42 & 256 \\
\hline Jhawani & 903 & Precipitation & Chitawan & 27.58 & 84.53 & 270 \\
\hline Hetaundan.f.i. & 906 & Climatology & Makwanpur & 27.42 & 85.05 & 474 \\
\hline Beluwa(manahari) & 920 & Precipitation & Makwanpur & 27.55 & 84.82 & 274 \\
\hline Bharatpur & 927 & Climatology & Chitawan & 27.67 & 84.43 & 205 \\
\hline
\end{tabular}


Table A2. Cont.

\begin{tabular}{|c|c|c|c|c|c|c|}
\hline Station Name & Station ID & Station Type & District & Latitude & Longitude & Altitude \\
\hline \multicolumn{7}{|c|}{ Upper tropical bioclimatic zone $(500-1000 \mathrm{~m})$} \\
\hline Baglung & 605 & Climatology & Baglung & 28.27 & 83.60 & 984 \\
\hline Beni bazar & 609 & Climatology & Myagdi & 28.35 & 83.57 & 835 \\
\hline Kushma & 614 & Climatology & Parbat & 28.22 & 83.70 & 891 \\
\hline Garakot & 726 & Precipitation & Palpa & 27.87 & 83.80 & 500 \\
\hline Khudi bazar & 802 & Climatology & Lamjung & 28.28 & 84.37 & 823 \\
\hline Pokhara airport & 804 & Aeronatical & Kaski & 28.22 & 84.00 & 827 \\
\hline Syangja & 805 & Climatology & Syangia & 28.10 & 83.88 & 868 \\
\hline Kunchha & 807 & Precipitation & Lamiung & 28.13 & 84.35 & 855 \\
\hline Bandipur & 808 & Climatology & Tanahun & 27.93 & 84.42 & 965 \\
\hline Malepatan & 811 & Agrometeorology & Kaski & 28.12 & 84.12 & 856 \\
\hline Khairinitar & 815 & Agrometeorology & Tanahun & 28.03 & 84.10 & 500 \\
\hline Arughatbazar & 1002 & Precipitation & Dhading & 28.05 & 84.82 & 518 \\
\hline \multicolumn{7}{|c|}{ Lower subtropical bioclimatic zone (1000-1500 m) } \\
\hline Tatopani & 606 & Precipitation & Myagdi & 28.48 & 83.65 & 1243 \\
\hline Tansen & 702 & Climatology & Palpa & 27.87 & 83.53 & 1067 \\
\hline Musikot & 722 & Precipitation & Gulmi & 28.17 & 83.27 & 1280 \\
\hline Jagat (setibas) & 801 & Precipitation & Gorkha & 28.37 & 84.90 & 1334 \\
\hline Gorkha & 809 & Agrometeorology & Gorkha & 28.00 & 84.62 & 1097 \\
\hline Lamachaur & 818 & Precipitation & Kaski & 28.27 & 83.97 & 1070 \\
\hline Pamdur & 830 & Precipitation & Kaski & 28.27 & 84.78 & 1160 \\
\hline Makwanpurgadhi & 919 & Precipitation & Makwanpur & 27.42 & 85.17 & 1030 \\
\hline Nuwakot & 1004 & Climatology & Nuwakot & 27.92 & 85.17 & 1003 \\
\hline Dhading & 1005 & Precipitation & Dhading & 27.87 & 84.93 & 1420 \\
\hline Pansayakhola & 1057 & Precipitation & Nuwakot & 28.02 & 85.12 & 1240 \\
\hline \multicolumn{7}{|c|}{ Upper subtropical bioclimatic zone (1500-2000 m) } \\
\hline Karki neta & 613 & Precipitation & Parbat & 28.18 & 83.75 & 1720 \\
\hline Khanchikot & 715 & Climatology & Arghakhanchi & 27.93 & 83.15 & 1760 \\
\hline Tamghas & 725 & Climatology & Gulmi & 28.07 & 83.25 & 1530 \\
\hline Lumle & 814 & Agrometeorology & Kaski & 28.30 & 83.80 & 1740 \\
\hline Ghandruk & 821 & Precipitation & Kaski & 28.38 & 83.80 & 1960 \\
\hline Chisapanigadhi & 904 & Precipitation & Makwanpur & 27.55 & 85.13 & 1706 \\
\hline Markhugaun & 915 & Precipitation & Makwanpur & 27.62 & 85.15 & 1530 \\
\hline Timure & 1001 & Climatology & Rasuwa & 28.28 & 85.38 & 1900 \\
\hline Thamachit & 1054 & Precipitation & Rasuwa & 28.17 & 85.32 & 1847 \\
\hline Dhunche & 1055 & Climatology & Rasuwa & 28.10 & 85.30 & 1982 \\
\hline \multicolumn{7}{|c|}{ Lower temperate bioclimatic zone $(2000-2500 \mathrm{~m})$} \\
\hline Lete & 607 & Climatology & Mustang & 28.63 & 83.60 & 2384 \\
\hline Bobang & 615 & Precipitation & Baglung & 28.40 & 83.10 & 2273 \\
\hline Daman & 905 & Climatology & Makwanpur & 27.60 & 85.08 & 2314 \\
\hline Kakani & 1007 & Agrometeorology & Nuwakot & 27.80 & 85.25 & 2064 \\
\hline \multicolumn{7}{|c|}{ Upper temperate bioclimatic zone $(2500-3000 \mathrm{~m})$} \\
\hline Jomsom & 601 & Climatology & Mustang & 28.78 & 83.72 & 2744 \\
\hline Thakmarpha & 604 & Agrometeorology & Mustang & 28.75 & 83.70 & 2566 \\
\hline Gurjakhani & 616 & Climatology & Myagdi & 28.60 & 83.22 & 2530 \\
\hline Chame & 816 & Climatology & Manang & 28.55 & 84.23 & 2680 \\
\hline \multicolumn{7}{|c|}{ Lower subalpine bioclimatic zone $(3000-3500 \mathrm{~m})$} \\
\hline Ghami (mustang) & 610 & Precipitation & Mustang & 29.05 & 83.88 & 3465 \\
\hline Manangbhot & 820 & Climatology & Manang & 28.67 & 84.02 & 3420 \\
\hline \multicolumn{7}{|c|}{ Alpine bioclimatic zone $(3500-4000 \mathrm{~m})$} \\
\hline Ranipauwa (m.nath) & 608 & Precipitation & Mustang & 28.82 & 83.88 & 3609 \\
\hline Mustang(lomangthang & 612 & Climatology & Mustang & 29.18 & 83.97 & 3705 \\
\hline Larkesamdo & 806 & Precipitation & Gorkha & 28.67 & 84.62 & 3650 \\
\hline
\end{tabular}

Source: Department of Hydrology and Meteorology. 


\section{References}

1. Palazzi, E.; Filippi, L.; Hardenberg, J.V. Insights into elevation dependent warming in the Tibetan plateau-Himalayas from CMIP5 model simulations. Clim. Dyn. 2016. [CrossRef]

2. DHM. Observed Climate Trend Analysis in the Districts and Physiographic Regions of Nepal (1971-2014); Department of Hydrology and Meteorology: Kathmandu, Nepal, 2017.

3. IPCC. Summary for Policymakers. In Global Warming of $1.5^{\circ} \mathrm{C}$. An IPCC Special Report on the Impacts of Global Warming of $1.5^{\circ} \mathrm{C}$ above Pre-Industrial Levels and Related Global Greenhouse Gas Emission Pathways, in the Context of Strengthening the Global Response to the Threat of Climate Change, Sustainable Development, and Efforts to Eradicate Poverty; Masson-Delmotte, V., Zhai, P., Pörtner, H.-O., Roberts, D., Skea, J., Shukla, P.R., Pirani, A., Moufouma-Okia, W., Péan, C., Pidcock, R., et al., Eds.; Cambridge University Press: Cambridge, UK, 2018.

4. Rangwala, I.; Miller, J.R. Climate change in mountains - a review of elevation dependent warming and its possible causes. Clim. Chang. 2012, 114, 527-547. [CrossRef]

5. MoFE. Climate Change Scenarios for Nepal for National Adaptation Plan (NAP); Ministry of Forests and Environment: Kathmandu, Nepal, 2019.

6. Parmesan, C.; Yohe, G. A globally coherent fingerprint of climate change impacts across natural systems. Nature 2003, 42, 37-42. [CrossRef]

7. Shrestha, M.L. Development of climate change scenarios with reference to Nepal. In Proceedings of the Workshop on Climate Change in Nepal; Department of Hydrology and Meteorology: Kathmandu, Nepal, 1997; pp. 16-32.

8. DHM. Proceedings of the Workshop on Climate Change in Nepal; Department of Hydrology and Meteorology: Kathmandu, Nepal, 1997.

9. Shrestha, A.B.; Wake, C.P.; Mayewski, P.A.; Dibb, J.E. Maximum temperature trends in the Himalaya and its vicinity: An analysis based on temperature records from Nepal for the period 1971-94. J. Clim. 1999, 12, 2775-2786. [CrossRef]

10. Baidya, S.K.; Regmi, R.K.; Shrestha, M.L. Climate Profile and Observed Climate Change and Climate Variability in Nepal; APN CAPABLE Report; Department of Hydrology and Meteorology: Kathmandu, Nepal, 2007.

11. Karmacharya, J.; Shrestha, A.; Shrestha, M.L. Climate Change Scenarios for South Asia and Central Himalayan Region Based on GCM Ensemble; APN CAPABLE Report; Department of Hydrology and Meteorology: Kathmandu, Nepal, 2007.

12. Baidya, S.K.; Shrestha, M.L.; Shiekh, M.M. Trends in daily extremes of temperature and precipitation in Nepal. J. Hydrol. Meteorol. 2008, 5, 38-51.

13. NCVST. Vulnerability through the Eyes of Vulnerable: Climate Change Induced Uncertainties' and Nepal's Development Predicaments; Institute for Social and Environmental Transition-Nepal (ISET-N, Kathmandu) and Institute for Social and Environmental Transition (ISET, Boulder, Colorado) for Nepal Climate Vulnerability Study Team: Kathmandu, Nepal, 2009.

14. Practical Action. Understanding Disaster Management in Practice with Reference to Nepal; Practical Action: Kathmandu, Nepal, 2009.

15. Shrestha, U.B.; Gautam, S.; Bawa, K.S. Widespread climate change in the Himalayas and associated changes in local ecosystems. PLoS ONE 2012, 7, e36741. [CrossRef]

16. Panthi, J.; Dahal, P.; Shrestha, M.; Aryal, S.; Krakauer, N.; Pradhanang, S.; Lakhankar, T.; Jha, A.; Sharma, M.; Karki, R. Spatial and temporal variability of rainfall in the Gandaki River Basin of Nepal Himalaya. Climate 2015, 3, 210-226. [CrossRef]

17. Nepal, S. Impacts of climate change on the hydrological regime of the Koshi river basin in the Himalayan region. J. Hydro-Environ. Res. 2016, 10, 76-89. [CrossRef]

18. Khatiwada, K.; Panthi, J.; Shrestha, M.; Nepal, S. Hydro-climatic variability in the Karnali river basin of Nepal Himalaya. Climate 2016, 4, 17. [CrossRef]

19. Agrawal, A.; Babel, M.S.; Maskey, S.; Shrestha, S.; Kawasaki, A.; Tripathi, N.K. Analysis of temperature projections in the Koshi River Basin, Nepal. Int. J. Climatol. 2016, 36, 266-279. [CrossRef]

20. Manadal, R.A. Weather station and annual temperature dynamics in the elevation gradient (spatial and temporal analysis of Chitwan-Annapurna, Nepal). J. Hist. Archeol. Anthropol. Sci. 2020, 5, 37-44.

21. MoFSC. Strategy and Action Plan 2016-2025, Chitwan Annapurna Landscape, Nepal; Ministry of Forests and Soil Conservation: Kathmandu, Nepal, 2015. 
22. Dobremez, J.F. Ecology and Biogeography of Nepal; National Scientific Research Centre: Paris, France, 1976. (In French)

23. TISC. Forest and Vegetation Types of Nepal; Tree Improvement and Silviculture Component (TISC), TISC documentation series No 105; Department of Forest, HMG/NARMSAP: Kathmandu, Nepal, 2002.

24. MoE. National Adaptation Programme of Action (NAPA) to Climate Change; Ministry of Environment, Government of Nepal: Kathmandu, Nepal, 2011.

25. Karpouzos, D.K.; Kavalieratou, S.; Babajimopoulos, C. Trend analysis of precipitation data in Pieria Region (Greece). Eur. Water. 2010, 30, 31-40.

26. Partal, T.; Kahya, E. Trend analysis in Turkish precipitation data. Hydrol. Process. 2006, 20, 2011-2026. [CrossRef]

27. R Core Team. R: A Language and Environment for Statistical Computing; R Foundation for Statistical Computing: Vienna, Austria, 2013; Available online: http://www.R-project.org/ (accessed on 21 March 2020).

28. Petersen, L.; Pellicciotti, F. Spatial and temporal variability of air temperature on a melting glacier: Atmospheric controls, extrapolation methods and their effect on melt modeling, Juncal Norte Glacier, Chile. J. Geophys. Res. 2011, 116, D23109. [CrossRef]

29. Kattel, D.B.; Yao, T.; Yang, K.; Tian, L.; Yang, G.; Joswiak, D. Temperature lapse rate in complex mountain terrain on the southern slope of the central Himalayas. Theor. Appl. Climatol. 2013, 113, 671-682. [CrossRef]

30. Tang, Z.; Fang, J. Temperature variation along the northern and southern slopes of Mt. Taibai, China. Agric. For. Meteorol. 2006, 139, 200-207. [CrossRef]

31. Shrestha, A.B.; Wake, C.P.; Dibb, J.E.; Mayewski, P.A. Precipitation fluctuations in the Nepal Himalaya and its vicinity and relationship with some large scale climatological parameters. Int. J. Climatol. 2000, 20, 317-327. [CrossRef]

32. Poudel, S.; Shaw, R. The relationships between climate variability and crop yield in a mountainous environment: A case study in Lamjung district, Nepal. Climate 2016, 4, 13. [CrossRef]

33. Luitel, D.R.; Siwakoti, M.; Jha, P.K. Relationship between Climatic Variables and Finger Millet Yield in Syangja, Central Nepal. J. For. Livelihood 2018, 16, 1-13.

34. McSweeney, C.; New, M.; Lizcano, G. Nepal. UNDP Climate Change Country Profiles Series. 2012. Available online: http://www.geog.ox.ac.uk/research/climate/projects/undp-cp/index.html?country=Nepal\& d1 =Reports (accessed on 20 March 2020).

35. DHM. Study of Climate and Climatic Variation over Nepal; A final report submitted to Ministry of science, technology and environment; Department of Hydrology and Meteorology: Kathmandu, Nepal, 2015.

36. MoSTE. Nepal Second National Communication to United Nations Framework Convention on Climate Change; Ministry of Science, Technology and Environment: Kathmandu, Nepal, 2014. Available online: http: //unfccc.int/resource/docs/natc/nplnc2.pdf (accessed on 20 March 2020).

37. Shrestha, M.L. Inter-annual variation of summer monsoon rainfall over Nepal and its relation to Southern Oscillation Index. Meteorol. Atmos. Phys. 2000, 75, 21-28. [CrossRef]

38. Dawadi, B. Climatic records and linkage along an altitudinal gradient in the southern slope of Nepal Himalaya. J. Nepal Geol. Soc. 2017, 53, 47-56. [CrossRef]

39. Kansakar, S.R.; Hannah, D.M.; Gerrard, J.; Rees, G. Spatial pattern in the precipitation regime in Nepal. Int. J. Climatol. 2004, 24, 1645-1659. [CrossRef]

40. Putkonen, J.K. Continuous Snow and Rain Data at 500 to $4400 \mathrm{~m}$ altitude near Annapurna, Nepal, $1999-2001$. Arct. Antarct. Alp. Res. 2004, 36, 244-248. [CrossRef]

41. WESC. Water Resources of Nepal in the Context of Climate Change; Water and Energy Commission Secretariat, Singhadurbar: Kathmandu, Nepal, 2011.

42. Sharma, K.P.; Vorosmarty, C.J.; Moore, B., III. Sensitivity of the Himalayan Hydrology to Land-use and Climatic Changes. In Climatic Change 47; Kluwer Academic Publishers: Dordrecht, The Netherlands, 2000; pp. 117-139.

43. Hansen, J.; Sato, M.; Ruedy, R.; Lo, K.; Lea, D.W.; Elizade, M. Global Temperature Change. Proc. Natl. Acad. Sci. USA 2006, 103, 14288-14293. [CrossRef] [PubMed]

44. Chen, B.; Chao, W.C.; Liu, X. Enhanced climatic warming in the Tibetan plateau due to doubling $\mathrm{CO}_{2}$ : A model study. Clim. Dyn. 2003, 20, 401-413. [CrossRef]

45. ICIMOD. Snow Cover Statistics- Nepal; E-bulletin: International Centre for Integrated Mountain Development (ICIMOD): Lalitpur, Nepal, 2013. 
46. Heynen, M.; Miles, E.; Ragettli, S.; Buri, P.; Immerzeel, W.W.; Pellicciotti, F. Air temperature variability in a high-elevation Himalayan catchment. Ann. Glaciol. 2016, 57. [CrossRef]

47. Immerzeel, W.W.; Petersen, L.; Ragettli, S.; Pellicciotti, F. The importance of observed gradients of air temperature and precipitation for modeling runoff from a glacierized watershed in the Nepalese Himalayas. Water Resour. Res. 2014, 50, 2212-2226. [CrossRef]

Publisher's Note: MDPI stays neutral with regard to jurisdictional claims in published maps and institutional affiliations.

(C) 2020 by the authors. Licensee MDPI, Basel, Switzerland. This article is an open access article distributed under the terms and conditions of the Creative Commons Attribution (CC BY) license (http://creativecommons.org/licenses/by/4.0/). 